\title{
English Language Learning of Indonesian Students during Study Abroad Program in Australia
}

\author{
Sabaruddin \\ Monash University, Australia
}

Abstract: This article discusses how the transformation of identity and cultural learning influence the English language learning of Indonesian students during their study program. This article is divided into three different sections of discussions in order to elaborate this issue comprehensively. Firstly, the identity change during the study abroad program is discussed by utilising the concept of identity. Subsequently, the process of identity transformation of Indonesian students during their study abroad is further elaborated through the identity movement theory. Secondly, the process of cultural learning during study abroad program is explained regarding English language learning of Indonesian students. Thirdly, how the students' identity transformation and cultural learning impact on English language learning is also be analysed. In conclusion, the role of identity transformation and intercultural learning is significant in the enhancement of English language proficiency of the students during the study overseas program. Furthermore, the process of English language learning transforms the students' identities through the students' engagement in the new sociocultural condition. The transformation of students' identity occurs in three steps of identity movement which are molar, molecular and line of flight identity. The transformation also lies in intercultural learning which later develops the students' intercultural awareness and understanding. That is to say, study overseas can transform the students' identity and facilitate cultural learning in which both are beneficial in enhancing the English language proficiency of the student. Besides that, study abroad program also constructs difference between individuals who pursue study overseas and who do not.

Keywords: Concept of identity, Cultural learning, Identity movement theory, Identity transformation, Studying overseas

\section{INTRODUCTION}

Study abroad trend has been overgrowing during the last few decades (Byram \& Feng, 2006). This rapid growth of study abroad is caused by the belief of individuals that through study abroad, they will gain many advantages such as enhancing intercultural awareness and enlarging their future life opportunities in the globalisation era (Mpinganjira, 2009; Norris \& Gillespie, 2009). Furthermore, based on research conducted by Elwood (2011), besides for completing degrees in overseas universities, another reason for students pursuing their study abroad is to enhance their foreign language proficiency. The study abroad allows the students to get a lot of interactions and high exposure of the language which can help them 
to improve their second or foreign language expertise significantly (Campbell, 2015). Therefore, it can be assumed that the students decide to pursue their study in abroad universities in order to gain the benefits of the study abroad including to develop their second or foreign language skills.

In line with this study abroad trend, a significant number of Indonesian students who continue their education overseas increases in the last few decades, and counties such as Australia, the United State, Canada, and England become the preferred destination for them to study (Primadhyta, 2017). This significant increment is affected by several reasons. First of all, since 2012, the Indonesian government has formulated a myriad of scholarship programs for study abroad which offers the Indonesian students abundant opportunities to pursue their higher education overseas (Tanuwidjaja, 2017). Secondly, as a response to the globalisation era in which English becomes an international language, Indonesian students also intend to improve their English language ability while continuing their academic degree abroad (Tanuwidjaja, 2017). Studying in English speaking countries, Indonesian students can involve in English language community and engage with the native speaker of the language which later helps them to acquire the language more naturally (Primadhyta, 2017). Therefore, the English speaking countries become favourable study destination for Indonesian students in order to continue their educational degree as well as to develop their English language proficiency.

Based on the phenomenon explanation above, English language learning of Indonesian students during their study abroad program will be discussed in this essay, especially for Indonesian students who study in Australia. In order to discuss English language learning process in study overseas, the concept of identity and culture should also be discussed as both ideas are essential in the language learning process (Sato, 2014). It is because in a language learning process, both language and culture are interrelated and understanding the culture of the language is possibly change the identity of students (Sato, 2014). Thus, how the transformation of identity and cultural learning influence the English language learning of Indonesian students during their study program will be investigated in this essay.

This essay will be divided into three different sections of discussions in order to elaborate this issue comprehensively. Firstly, the identity change during the study abroad program will be discussed by utilising the concept of identity. Subsequently, the process of identity transformation of Indonesian students during their study abroad will be further elaborated through the identity movement theory offered by Deleuze and Gauttari (1987 as cited in Elwood, 2011). Secondly, the process of cultural learning during study abroad program will be explained regarding English language learning of Indonesian students. Thirdly, how the students' identity transformation and cultural learning impact on English language learning will also be analysed. Furthermore, the reflection of my study abroad experience will be exposed. Then, the implication and limitation of this investigation will be provided. In the end, a conclusion will be served to summarise the essential information of this essay. 


\section{DISCUSSION}

\section{Identity Transformation}

Before going further to investigate the identity transformation of Indonesian students during their study abroad program, it is essential to define "what is identity" and how this concept works in shaping new identities of students studying overseas. Thus, in this part, first of all, the discussion about the idea of identity will be provided before investigating how the identity of Indonesian students transforms during their study program.

\section{The Identity Concept}

Identity is a complex issue and it crucial aspect in determining the position of individuals in social communities. In order to explain the concept of identity, some definitions from experts will be discussed. According to Woodward (1997), Identity is the way we position ourselves within a society as well as in the world. Additionally, Jenkins (1994) defines identity as a social classification process which is significantly influenced by "the production and reproduction of social identities" of individuals in their social life (p. 197). Furthermore, identity is something which is not fixed, "but it is fragmented and contested in nature" (David, 2007, p. 864). Identity is also interpreted as the emotion of people in relation to the world around them (Goldoni, 2017). Thus, it can be concluded that identity is the concept of the way we perceive ourselves within a sociocultural community as well as in the world we live in which the identity of individuals will always evolve as a response to different social and cultural conditions.

There are two main perspectives regarding the notion of identity. The first is an essential perspective. In the view of essentialism, identity is something stable, fixed and unchangeable (Woodward, 1997). This notion is heavily seen the identity from ethical and historical aspects of individuals (Hall, 1990). For example, someone who is born in a particular ethnic group will always be indicated as a member of the group such as Javanese, Buginese, and many others. This ethnic identity is fixed, and it cannot be changed (Kramsch, 1998). The second perspective is non-essentialism which is quite contradictive with the essentialism. The non-essentialism interprets the identity as something fluid which can be constructed within new sociocultural situations (Du Gay \& Hall, 2003). This idea is also straightened by Kersten and Abbott (2012) who claim that individuals have an authority to position themselves within a new situation which latter will identify "who are they" in that situation. The sample of this perspective is cultural identity. According to Duany, Xe, and Rez, (2000), culture is viewed as a contested representation which has possibly to evolve rather than a fixed entity. In other words, the cultural identity of people can be changed as a response to the new cultural circumstances. In essence, non-essentialism recognises the identity as a process of being and becoming as a response to new social and cultural circumstances instead of fixed and unchangeable (Hall, 1990; Bright, 2017).

In terms of identity changes in students during the study abroad program, non-essentialism is more applicable to explain the process of students' identity transformation rather than essential perspective. It is because non-essentialism perspective admits that identity is changeable, flexible which always transforms 
within an individual across the time (Hall, 1997). In addition, the identity of people in a community can be determined based on their recent identifications (Elwood, 2011). For example, Indonesian students who use the Indonesian language as their first language will be identified as Indonesian when the first time come to Australia. However, after several mounts interacting in Australian social and academic life, they will not only be considered as Indonesian but also as international students who utilise English in their social and academic interaction. This transformation occurs because identity is flexible which can evolve within new environments (Hall, 1997). Additionally, the students have many chances to engage with many domestic students as well as other international students that can expose them to different cultures, languages, and personalities. As a result, those interactions will allow the students to position themselves within the situations and build new identities during their study in Australia. That is to say that the identity transformation of Indonesian students possibly happens during their study abroad program.

In order to investigate the identity transformation of Indonesian student during their study abroad in Australia, the theory of identity movement which is proposed by Deleuze and Gauttari (1987, as cited in Ellwood, 2011) will be applied. They claim that the transformation of identity consists of three movements which are molar, molecular and line of flight movement. Therefore, in the next discussion, the theory of identity movement will be explained in-depth to explore the identity changes of Indonesian students during the study in Australia.

\section{Transformation of Students' Identity during the Study Overseas Program}

Identity is possibly changed and developed during study abroad because it is unfixed, changeable and not-essential (Du Gay \& Hall, 2003). In this part, therefore, the identity transformation of students will be explained through the identity movement theory offered by Deleuze and Gauttari. Deleuze and Gauttari divide the identity transformation process into three steps (1987, as cited in Elwood, 2011). The first step is a molar identity. The molar identity is described as bounded identities that have been already attached in ourselves (Deleuze \& Gauttari to, 1987, as cited in Elwood, 2011). It is also interpreted as a set of cultural discourse which is tied to someone's identity (Elwood, 2011). The molar identity refers to the people identity which shows the status of being in a particular social and cultural situation (Kinginger, 2013). As an illustration, Indonesian students who are joining the study abroad program in Australia will bring their prior identities and habitual activities which have been constructed in their home country. They are identified themselves as an Indonesian, alumni of Indonesian university, chief of an organisation, or a specialist in a specific field of work and many others. Those identities established before study abroad program are categorised as molar identities (Elwood, 2011).

The second step is a molecular identity. In this step, people are able to influence other's identities and vice versa during the social and cultural interactions (Deleuze \& Guattari, 1987, as cited in Ellwood, 2011). Regarding study abroad program, it is the step where the identity of international students is affected by the new sociocultural circumstances where they study which can influence or change their molar identities (Campbell, 2015). According to Elwood 
(2011), the students' response and adaptation to the new situations are possibly constructed new identities. For example, Indonesian students in Australia will adjust their habit in term of toilet use in which Indonesians are used to utilise wettype of the toilet instead of a dry one. In this situation, the Australian sociocultural setting forces Indonesian students to change their identity from users of the wettype toilet to dried one. Therefore, the response of Indonesian students to the new sociocultural situations in Australia affects their identity development.

The third step is the lines of flight identity. According to Elwood (2011), in this step, individuals start to open their mindset for potential changes regarding their identity. Regarding the study abroad setting, this step occurs when the students open their mind as the way to adapt the sociocultural environment around them (Elwood, 2011). The students begin to recognise what is right and proper or wrong in order to act appropriately in the new environment where they live (Kinginger, 2013). For instance, Indonesian students who always make ridiculous jokes such as laughing when their friend makes a mistake will adjust the behaviour because it is considered rude and impolite in Australian culture. Sawir (2005) argues that through the adjustment of their behaviour, they begin to transform their identity to become more Australian which may help them mingle and socialise with the local people properly. Therefore, Indonesian students' awareness of the set of Australian cultural norms transforms their identities during the study program.

From the explanation above, it can be stated that the identity of Indonesian students studying abroad might also evolve when the students learn English. Elwood (2011) contends that the issue of identity transformation of students is essential in foreign language learning because it can affect the learning process. For instance, Indonesian students who identify themselves as an English learner will have a high motivation to engage in English environment where they can practice their English. Through the active engagement, the students will acquire the language more easily. In addition, the notion of cultural learning should also be considered because it assists the students to learn the language during their study abroad program (Watson \& Wolfel, 2015). By knowing the culture of the target language, the students can use the language appropriately (Kramsch, 1998). Furthermore, Kasper and Omori (2010) argue that the correlation between language learning and culture is complicated. Therefore, before discussing how the three identity movements influence the English language learning of Indonesian students, the notion of culture will be explained in the next section.

\section{Cultural Learning}

Understanding the concept of culture is essential because it helps to elaborate the way the students learn the culture. Thus, in this section, the notion of culture will be initially explained before elaborating the process of cultural learning of Indonesian students studying abroad.

\section{The Concept of Culture}

There are some views regarding the concept of culture. According to Hall (2013), people who belong to a particular culture will perceive the world roughly in the same way. In other words, the culture is understood as shared meanings and conceptual maps among the members of a community (Du Gay \& Hall, 2003). 
This idea is also supported by Kramsch (1998) who claims that people who are identified as a part of a specific cultural community will acquire the similar perspective of the world as a result of frequent engagements and interactions with the participants of the cultural groups. As an illustration, Indonesian people who speak the same language share similar conceptual maps as well as meanings which allow them to communicate meaningfully within Indonesian culture. It is because they perceive the world roughly in similar perception.

In addition, the same viewpoint of individuals towards the world distinguishes them from the members of other cultural communities (Woodward, 1997). Every culture has uniqueness and difference in perceiving the world (Kramsch, 1998). Thus, the differences between Indonesian and Australian culture become an essential issue in investigation how the Indonesian students learn the Australian culture. Therefore, the discussion on how they deal with the cultural difference during their study program will be explained in the next section.

\section{Cultural Immersion in Study Abroad Program}

As explained in previously, people will be categorised as a member of a specific sociocultural community if the people share the same conceptual maps as well as the meaning towards the world around them (Hall, 2013). For instance, Indonesian students belong to Indonesian culture before continuing their study overseas, but the sense of belonging to the Indonesian culture will change after a long time staying abroad. It is because acculturation and assimilation between the prior culture of the students and culture where they study might occur through the intense interaction of the students in the new cultural environment (Tian \& Lowe, 2013). In this circumstance, the students will adapt to the novel culture situation which might change their cultural perspective (Campbell, 2015).

In addition, during the cultural immersion process, students might face several challenges. Tian and Lowe (2013) contend that students might struggle or even fell stress to adapt to the new cultural circumstance. For instance, the Indonesian students will probably be frustrated in terms of the language used in University as well as in society at the beginning of their study in Australia. Nevertheless, the frustration or cultural shock will decrease gradually because of the proper adaptation of the students to the new cultural environment where the language is spoken (Campbell, 2015). In the adaptation process, the cultural identities of the students are transformed through repositioning their cultural perspective within the new culture condition (Australian Culture) (Elwood, 2011). Therefore, in order to immerse within the Australian culture, a proper adaptation of Indonesian students towards the culture is essential.

The cultural immersion during study overseas is also known as intercultural learning (Tsai, 2012). According to Tian and Lowe (2013), the crosscultural learning process can improve the cognitive ability, cultural awareness, and emotional sensibility of the students to the different cultural circumstances which results in the development of two prominent competencies which are individualisation and universalisation. Individualisation is an ability to value other people as unique, while universalisation is a capability to build harmonies among people from a different culture (Tian \& Lowe, 2013). Therefore, intercultural understanding develops the students' cultural awareness (Campbell, 2015). 
Intercultural learning of study abroad students is interlinked with the language learning process. According to Ingram (2005), the students studying abroad either for short course or for the academic degree will acquire and learn the original culture as well as the cognitive competence of language which is spoken in the cultural communities where they study. For example, Indonesian students studying in Australia will interact with the culture where English is used as a means of communication. Interacting more frequently with the culture, the students will acquire how to use English appropriately within the Australian culture. Nonetheless, the significant influence of intercultural competence in the improvement of foreign language skills is still a debatable issue. Watson and Wolfel (2015) claimed that the foreign language competence of students will not be significantly developed through intercultural competence during the study abroad program. That is to say that, there are some other essential factors that students need to take into account in order to develop English language proficiency during their study overseas.

After explaining the identity change and cultural learning of students during the period of study abroad, the investigation regarding the correlation between English language learning process, identity transformation, and cultural immersion will be elaborated in the next section of this essay. The purpose of this essay is to investigate how the connection of those notions affects the process of English language learning and acquisition of Indonesian students who study in Australia. The investigation will specifically find out to what extent the identity transformation and cultural awareness influence the development of English language skills of the students during the period of their study abroad program.

\section{The Language Learning in Study Abroad}

In the last decades, study abroad becomes popular among the students in Indonesian. It is caused by the availability of scholarships offered by the Indonesian government for the students to pursue their study overseas (Tanuwidjaya, 2017). In addition, English speaking countries become favourable destinations for them (Primadhyta, 2017). The reason behind their decision to pursue their degree in those countries is that they also would like to improve their English language proficiency (Primadhyta, 2017). Nevertheless, the issue of identity transformation and cultural immersion occurring during the study abroad might influence the enhancement of English language proficiency of the students.

Before going further to explain their impact of identity transformation and cultural learning on the development of students' English language skills, it is valuable to consider the primary purpose of language learning itself. According to Hall (1997), language is a means to create and exchange meaning which is facilitated through the system of representation. Through the representation system, individuals can communicate and express their ideas and thoughts (Hall, 1997). Furthermore, Kramsch (1998) argues that language incorporates symbols or signs in producing meaning in communication. Thus, it can be stated that learning a language is to acquire the symbols as well as the sings of the language and this can be gained through active participation in the culture where the language is spoken (Hall, 1997). Regarding study abroad, it is seen that communicative competence becomes the primary goal of language learning 
(Moreno, 2009). Moreno (2009) contends that the program can positively impact on the linguistic acquisition, narrative competence, and communicative skill of students studying abroad.

Furthermore, Campbell (2015) argues that the learning of foreign language is feasible through the active interaction of the students to the target language environment which can be experienced through study abroad. In this interaction, students will frequently produce meaningful utterance and message in a particular context of conversation resulting in the development of their communicative competence (Kramsch, 2009 as cited in Harmer, 2015). Therefore, the students are able to acquire the communicative competence of the language as they get multiple opportunities to engage with English language environment during the study abroad program (Kramsch, 2009 as cited in Harmer, 2015). For example, the students can communicate directly with native speakers of English as well as other international students speaking English fluently during study abroad program enabling them to enhance their English communicative skill.

Apart from gaining the communicative competence, the students also can improve their lexical comprehension and linguistic competence during the language learning (Moreno, 2009). The development of those competencies which is also known as strategic competence is affected by the number of courses taken during their study abroad program (Savicki, 2011). Through their involvement in classrooms which are conducted using English as a medium of instruction, they will get high exposure of English which is beneficial for enhancement of their English skills (writing, speaking, reading, and listening) (Savicki, 2011). Thus, communicative and linguistic ability can be gained by the students through studying abroad. In addition, those language competencies can be achieved along with the cultural learning process and identity change during the study overseas period (Campbell, 2015). Therefore, how the identity change, cultural immersion and English language learning are connected in the study abroad program will be explained in the subsequent discussion.

\section{The Interconnection of Cultural Learning, Identity Change, and English Language Learning in Study Abroad Program}

To explain in depth, the identity movement and cultural learning which have been elaborated above will be discussed in relation to English language learning within study overseas program. It will explain how those notions are connected and how the connection between those concepts influences the improvement of students' English language skills in study abroad context.

A foreign language learning process is significantly related to the identity transformation and intercultural understanding of students (Savicki, 2011). It is because the students' involvement in foreign language communication in the country where they study will open their mind regarding the new culture of the language that can change their position within the new sociocultural condition (Savicki, 2011). Additionally, study abroad program provides authentic language environment in which they have abundant chances for the students to acquire the native communities' speeches (Kinginger, 2008). The ample access to the native language resources allows the student to intensely communicate with the English native speakers which is useful to develop the students' English language 
competences (Campbell, 2015). As an example, Indonesian students studying in Australia have abundant opportunities to engage with Australian culture. Through active engagement, the students will acquire how to use English within Australian culture which helps them to improve their English communicative ability.

In addition, the intense interaction of students in the social groups during the study abroad period could assist the students to gain an intercultural communicative skill (Tsai, 2012). Gaining the skill will encourage the students to involve more in the local community where they study enabling them to cope with different culture-bound perspectives, rebuild their perception of certain cultural conceptions, and subsequently enhance their cultural awareness and belief of the new culture (Lahdenpera, 2000 as cited in Tsai, 2012). Furthermore, intercultural awareness affects the enhancement of the motivation of students in learning the language, and high motivation of students positively influences the learning process of the language (Tsai, 2012). For instance, Indonesian students who understand the Australian culture are eager to engage more in English language communication because they know how to speak and act within the Australian culture. The communicative engagement of the students helps them to acquire the language quickly (Campbell, 2015). Therefore, study abroad program provides the students many opportunities to involve more in cultural community in order to learn strategic, discourse and sociocultural aspects of the language allowing them to develop their communicative skill (Campbell, 2015).

Regarding the explanation above, the theory of identity movement possibly influences the development of English language expertise of the students. The movement of the students' identity can happen because of several reasons. Firstly, in molar identity step, Indonesian students attach themselves with prior identities before studying abroad. For example, the Indonesian students are likely to communicate with other Indonesians using the Indonesian language at the beginning of their commencement. However, by affected by local culture and language of Australian communities in which Australian people use English in their communication, the Indonesian students' molar identity as Indonesian language speaker is transformed to become an English user in order to communicate with the local people. In this step, the molecular identity movement happens where their identity can affect as well as be influenced by the new cultural environment of the country where they live in (Elwood, 2011). This identity change comes along with the process of cultural immersion and language learning during the study abroad program (Tian \& Lowe, 2014). In the next identity movement which is the line of flight step, the students have many opportunities to construct newness through their openness and engagement in the new environment around them. The identity movement process shows how the students socialise within the local sociocultural situation where they are learning and acquiring English in order to improve their communicative competences during their study abroad program. Thus, the identity movement will always occur during the study abroad program because the students' identity is fluid, changeable and unfixed (Hall, 2013; Savicki, 2011). 


\section{Reflection of My Personal Experience}

Discussing the transformation of identity, cultural immersion and English language learning and acquisition within the context of study abroad, I can reflect my study experience in Australia. From that experience, I can understand that my identities are changed during the period of my study program. Coming to Australia, I bring my prior identities which have been attached within myself, for instance, I am an Indonesian. I am an Indonesian language native speaker; I am an English teacher in one of secondary school in Indonesia, and so on. Those identities are molar identities that I brought from my home country that is transformed during my study in Australia since identity is changeable and fluid (Du Gay \& Hall, 2003).

At the first time arriving in Australia, I was struggling to understand Australian accent as well as the culture of Australian people. This circumstance forces me to learn more about the accent as well as the culture of Australian people in order to communicate with them appropriately. This is positioned my self in the molecular identity movement. Nevertheless, through my engagement with Australian communities, I started to figure out the way Australian people speaking English, and I got used to their culture gradually. Engaging with the culture of Australian people enhance my ability to gain English communicative competences. As a result, I get used to how they speak and produce meaning in English as well as knowing the way Australian people incorporate their culture in communication. This is where the line of flight stage happens in the context of my study abroad in Australia.

From that experience, I realised that by learning the Australian culture and involving myself in the English language environment both on a daily basis as well as academic context enhance my English language proficiency. Nonetheless, the more I learn the culture of the Australian people and acquire the English language, the more I recognise that my prior identity an culture are transformed as a response to the language and culture differences which exist in the new environment during the period of my study in Australia. Furthermore, my adaptation to the differences positively affects the improvement of English language competences of mine.

In addition, study abroad creates different identities between the students who study in Indonesian universities and I. Identity can be described as a process of classifying ourselves and the other as to whether we are same or different (Hall, 1997). In line with the experience explained above, it can be said that having the opportunity to study abroad constructs difference between my friends who only study in Indonesian university and I. It is because I can construct an identity which they cannot. For example, I can hold identity as international students, English user, and Australian cultural learner. In addition, I also can develop an intercultural understanding as well as acquire the English language naturally in which all of them are gained through the study abroad program. Furthermore, the difference can be perceived positively as well as negatively (Hall, 1997). The difference can be perceived positively through respect and appreciations. However, it can also be treated negatively through stereotyping and neglecting (Hall, 1997). In my condition, the difference might be perceived in a positive way 
which can be seen from the appreciations of my friends and relatives regarding my success to study abroad. Therefore, study abroad can also act as a marker of difference.

\section{IMPLICATION AND LIMITATION}

The discussion of this essay has implication to the study abroad program. From the discussing, it can be observed that the transformation of identity and cultural learning during the study program influence the development of students' English language proficiency significantly (Elwood, 2011; Campbell, 2015). The development of language skills can be gained through frequent interactions in the English language environment (Campbell, 2015). Through the involvement and engagement in that environment, the students learn the culture of the language and transform their identity as the way to adapt to the different sociocultural conditions (Elwood, 2011). Therefore, intercultural learning and identity transformation helps the students develop English language skills.

In relation to English language learning, it is suggested for students who intend to enhance their English language proficiency to continue their study overseas, especially in English speaking countries since it has many benefits for developing their English language abilities. Thus, as an implication, this essay suggests Indonesian government maintains and allocates more fund for study abroad scholarships. It is because study abroad program has positive impacts on the development of English language proficiency as well as intercultural awareness of Indonesian students that will be beneficial for them to compete with other individuals from different countries in this globalisation era.

Nevertheless, this paper has also several limitations. This essay focuses on analysing the connection of students' identity change, cultural immersion, and English language learning during the study overseas context. As a consequence, other aspect of English language learning is not fully covered. Also, the context of this essay is Australia which might be different from other countries. The identity transformation and cultural immersion process might occur differently in different countries. Thus, the investigation regarding influences of identity change and intercultural learning to foreign language proficiency in different sociocultural backgrounds is suggested to provide a comprehensive discussion regarding the benefit of study overseas program.

\section{CONCLUSION}

In conclusion, the role of identity transformation and intercultural learning is significant in the enhancement of English language proficiency of the students during the study overseas program. Furthermore, the process of English language learning transforms the students' identities through the students' engagement in the new sociocultural condition. The transformation of students' identity occurs in three steps of identity movement which are molar, molecular and line of flight identity. The transformation also lies in intercultural learning which later develops the students' intercultural awareness and understanding. In addition, English language learning process of students can be successful if the students are willing to socialise and intensely involve in the culture of the county they study. The 
frequent socialisation of students will impact on the level English language ability of the students. That is to say, study overseas can transform the students' identity and facilitate cultural learning in which both are beneficial in enhancing the English language proficiency of the student. Besides that, study abroad program also constructs difference between individuals who pursue study overseas and who do not.

\section{REFERENCES}

Byram, M., \& Feng, A. (2006). Living and studying abroad : Research and practice. Clevedon, United Kingdom: Multilingual Matters.

Campbell, R. L. (2015). Interaction and social networks with target language speakers during study sbroad and beyond: The experiences of learners of Japanese (dissertation). Monash University, Melbourne, Australia.

David, B. (2007). The rise of identity in SLA research, post Firth and Wagner (1997). The Modern Language Journal, 91(1).

Duany, J., Xe, \& Rez, L. A. (2000). On becoming Cuban: Identity nationality, and culture. The American Historical Review, 105(5).

Du Gay, P., \& Hall, S. (2003). Introduction: who needs 'identity?: Questions of cultural identity. London: Sage Publications.

Ellwood, C. (2011). Undoing the Knots: Identity transformation in a study abroad program. Educational Philosophy and Theory, 43(9), 960-978.

Goldoni, F. (2017). Race, ethnicity, class and identity: Implications for study abroad. Journal of Language, Identity \& Education, 16(5), 328-341.

Hall, S. (1990). Cultural identity and diaspora. In K. Woodward (Eds.), Identity and Difference (51-59). London: SAGE Publications.

Hall, S. (1997). The spectacle of the 'other'. In S. Hall (Ed.), Representation: Cultural Representations and Signifying Practices (pp. 225-238). London: Sage in association with Open University.

Hall, S. (2013). The work of representation. In S. Hall, J. Evans, \& S. Nixon (Eds.), Representation (1-47). London: Sage in association with The Open University.

Harmer, J. (2015). The practice of English language teaching (5th ed.). Harlow: Pearson Education Limited.

Ingram, M. (2005). Recasting the foreign language requirement through study abroad: A cultural immersion program in Avignon. Foreign Language Annals, 38(2), 211-222.

Jenkins, R. (1994). Rethinking ethnicity: Identity, categorization and power. Ethnic and Racial Studies, 17(2), 197-223.

Kasper, G., \& Omori, M. (2010). Language and culture. In McKay, S. L., \& Hornberger, N. H. (eds.) Sociolinguistics and Language Education. Clevedon: Multilingual Matters. 
Kersten, A., \& Abbott, C. (2012). Unveiling the global spectacle: Difference, identity and community. Culture and Organization, 18(4), 323-335.

Kinginger, C. (2013). Identity and language learning in study abroad. Foreign Language Annals, 46(3), 339-358.

Kramsch, C. (1998). Language and culture. Oxford: Oxford University Press.

Moreno, K. H. (2009). The study abroad experiences of heritage language learners: Discourses of identity. Austin: Proquest Dissertations Publishing.

Mpinganjira, M. (2009). Comparative analysis of factors influencing the decision to study abroad. African Journal of Business Management, 3(8), 358-365.

Norris, E. M., \& Gillespie, J. (2009). How study abroad shapes global careers. Journal of Studies in International Education, 13(3), 382-397.

Primadhyta, S. (2017). Inggris jadi Negara Tujuan Utama Para Pemburu Beasiswa [England becomes the most popular destination country for scholarship hunters]. Available https://www.cnnindonesia.com/ekonomi/2017013118303778190376/inggris-jadi-negara-tujuan-utama-para-pemburu-beasiswa/ [Verified 01 May 2018]

Sato, T. (2014). The effects of study abroad on second language identities and language learning. Turkish Online Journal of Qualitative Inquiry, 5(3).

Savicki, V. (2011). Relationship of foreign language proficiency to study abroad outcomes and inputs. The Interdisciplinary Journal of Study Abroad, 21(1), 63-85.

Sawir, E. (2005). Language difficulties of international students in Australia: The effects of prior learning experience. International Education Journal, 6(5), 567-580.

Tanuwidjaja. (2017). Indonesia - education and training. Available at https://www.export.gov/article?id=Indonesia-Education-and-Training [Verified 02 May 2018]

Tian, M., \& Lowe, J, A. (2014). Intercultural identity and intercultural experiences of American students in China. Journal of Studies in International Education, 18(3), 281-297.

Tsai, Y. (2012). The Effects of intercultural learning on English learning motivation among students studying abroad. New Horizons in Education, 60(1) 23-34.

Watson, J. R., \& Wolfel, R. (2015). The intersection of language and culture in study abroad: Assessment and analysis of study abroad outcomes. Frontiers: The Interdisciplinary Journal of Study Abroad, 25, 57-72.

Woodward, K. (1997). Concepts of identity and difference. In K. Woodward (Ed.), Identity and Difference ( 8-50). London: Sage in association with Open University. 